\title{
PAST IN THE PRESENT: MOUNT ŚLĘŻA ACCORDING TO PIERRE NORA'S "SITES OF MEMORY” (LIEUX DE MÉMOIRE) CONCEPT
}

\author{
PRZESZŁOŚĆ WE WSPÓŁCZESNOŚCI: GÓRA ŚLĘŻA \\ W KONCEPCJI „MIEJSC PAMIECCI” (LIEUX DE MÉMOIRE) \\ PIERRE'A NORY
}

\author{
Michat Pawleta \\ Instytut Archeologii. Uniwersytet im. Adama Mickiewicza w Poznaniu \\ ul. Umultowska 89D, 61-614 Poznań, Polska \\ mpawleta@amu.edu.pl
}

\begin{abstract}
In article I propose taking a look at the Mount Ślęża in Poland in the context of Pierre Nora's lieux de mémoire concept. Ślęża is an important heritage site as although it has been the topic of many studies and scientific investigations, interest in this unusual mountain goes well beyond scientific discourse. This paper focuses on not only what Ślęża meant to prehistoric people but mainly on its contemporary significance, with specific attention to the various functions that it fulfils today. By revealing the breadth of discourses on Ślęża and highlighting its vitality and relevance in the lives of many people, it also attmpts to put forward a dialogue between archaeologists, heritage professionals and groups holding alternative views on the current meaning or role of the Mount Ślęża.
\end{abstract}

KEY WORDS: Mount Ślęża, lieux de mémoire, heritage sites, stakeholders, dialogue

\section{INTRODUCTION}

Mount Ślęża, also called “The Silesian Olympus” (Cehak-Hołubowiczowa, 1953), is an iconic site on the map of Lower Silesia. Visible from tens of kilometres away, surrounded by numerous legends and enmeshed in local folklore, it has been an important site for tourists for many years and the subject of interest for a large group of scientists. The area around the foot of the mountain has been inhabited for thou- 
sands of years, as we know from archaeological evidence. The slopes and peak of the mountain are surrounded by mysterious stone circles, and equally enigmatic stone sculptures have been found nearby. It is generally assumed that Ślęża was an important cult and religious pagan centre in the Early Middle Ages until the early $12^{\text {th }}$ century (Szafrański, 1979, p. 209; Słupecki, 1992, p. 4; 1994, pp. 172-176; but see Mierzwiński, 2007).

From the perspective of the issues which this paper discusses, Ślęża is important as although it has been the topic of many studies and scientific investigations, interest in this unusual mountain goes well beyond academic discourse. Thus, this article focuses on its contemporary significance. I propose taking a look at the Mount Ślęża in the context of Pierre Nora's "sites of memory" (lieux de mémoire) concept which I regard to be of use in research into the presence of heritage in contemporary world, especially from the diverse aims which it fulfills in the present and the narratives created around it by different groups of people.

The article is divided into five parts. First, it discusses two major categories, namely "sites of memory", and "the history of the second degree", considered as useful concepts used to investigate the contemporary meanings of heritage sites. Second, it outlines theoretical basis of a heritage concept as approached in this paper and identifies the consequences of a statement that it no longer belongs to the past but is created in the present. Third, it presents different attitudes to the Mount Ślęża outside the academic discourse and outlines its importance in the present and its impact on the contemporary social imaginarium. The fourth element of the discussion analyzes these various approaches towards Mount Ślęża within the context of the "sites of memory" concept. Last part of a paper concentrates on justifying the need to open up a dialogue between archaeologists, heritage professionals and groups holding alternative views on the current meaning or role of this heritage site.

\section{SITES OF MEMORY (LIEUX DE MÉMOIRE)}

Maurice Halbwachs (1969) was the first to use the term "collective memory". He suggested that all individual memory was constructed within social structures and institutions. French sociologists stated also that every collective memory is depended upon specific groups that are delineated by space and time. His successors (e.g. Connerton, 1989; Assmann, 2008) have acknowledged the decisive role that the collective memory plays and have regarded memory as a part of a common vision of the past, as the transmission of values and certain patterns of behaviour, as well as the symbolization of a community and sense of belonging to a group of people. Although memory can be manifested in immaterial forms, such as narratives, myths or stories, it can also be materialized in artifacts, places, landscapes or be inscribed in texts, monuments and other forms of representation. 
Taking into consideration the specificity of heritage, especially promising is an aspect of materialization of social memory. Quite useful in this respect seems to be two concepts, namely "sites of memory" and "history of the second degree", introduced by Pierre Nora (1989). The concept of lieux de mémoire, or "sites of memory" quite quickly gained in popularity among scholars. Nora has never formulated a systematic theory of "sites of memory". Generally speaking, he used this concept to refer to all signs of national, public and social memory. It should rather be understood as a metaphor or a topos; it not only refers to sites marked on a map but actually has a much wider scope. Nora (1989, pp. 18-19) wrote: "Lieux de mémoire are simple and ambiguous, natural and artificial, at once immediately available in concrete sensual experience and susceptible to the most abstract elaboration. Indeed, they are lieux in three senses of the word - material, symbolic, and functional". Sites of memory can be material but also immaterial: it may well be a specific physical location but it also encompasses real and mythical figures and events, buildings, monuments, institutions, ideas, rituals, symbols etc., which have become a permanent element in collective memory. Thanks to human will or the passage of time they have become a symbolic element of the heritage of a particular community's memory. However, lieux de mémoire do not have an ahistorical or fixed meaning but are assigned diverse values by people in different times and places. As a consequence, their significance can often be contested, making them a subject of heated social or political debates. So, they can be regarded as hybrid places that "only exist because of their capacity for metamorphosis, an endless recycling of their meaning and an unpredictable proliferation of their ramifications" (Nora, 1989, p. 19).

In order to investigate such sites, Nora proposed a perspective he called "history of the second degree" (histoire au second degrê). It queries, amongst others, how collective images of the past began, the changes they are undergoing and the role of memory in the processes involved in the construction of collective identity. "History of the second degree" can be thus defined as history that is interested in memory, yet not as a remembrance but as the overall structure of the past within the present. This perspective thus points our attention to the "plurality of meanings obtained by remains being re-read, translated and negotiated by new people in new contexts" (Zalewska, 2012, p. 61). The key role in this perspective is played by the analysis of three elements of sites of memory, namely material, functional and symbolic (Kończal, 2009, p. 211). The history of the second degree can be characterized, inter alia, by a high degree of self-reflection which allows questioning the truths previously taken for granted. Moreover, it always asks for the reference of the present to the past, does not promote grant narratives but instead, it focuses on the multidimensionality and diversity of interpretations of the past (Kończal, 2009, pp. 220-221).

Nora (1989, pp. 20-21) claimed that even some sites or objects seem to fit by definition to lieux de mémoire, they should in fact be excluded due to the absolute absence of a will to remember them. While the above statement can be true in a case of numerous archaeological or heritage sites which are not "commemorated" any 
longer, the case of the Mount Ślęża clearly seems to defy it. Quite the contrary, it appears to be a "living" site, present in an academic discourse as well as outside it, to which different groups of people for various reasons and purposes refer. However, before returning to this point, it it perhaps helpful in the first instance to outline briefly what is heritage and how it is approached in this paper.

\section{HERITAGE IN THE PRESENT: CONTESTED VALUES, DIFFERENT STAKEHOLDERS}

Heritage is a wide concept and there is no consensus on the definition of this term as its meaning has changed over time (Harvey, 2001; Harrison, 2013). In a common sense assumption 'heritage' is identified as "'old', grand monumental and aesthetically pleasing sites, buildings, places and artefacts" (Smith, 2006, p. 11). The content of heritage is commonly seen as embracing both the material (or tangible) objects - natural landscapes, buildings, monuments etc. - but it also consists of immaterial (intangible) elements: traditions, oral history, performing arts or social practices (Graham, Howard, 2008, p. 3). Heritage is something that is handed down from the past and must be kept for future generations. As such, it includes preserving, excavating, displaying, restoring and protecting.

However, as Laurajane Smith argues (2006, pp. 29-34), it is rather a hegemonic discourse about heritage that naturalizes some aspects related to that heritage: she calls it "the authorized heritage discourse" (AHD). This discourse has been historically and institutionally constituted and authorized internationally by heritage bodies and their legislative acts. According to her, it "reinforces ideas of innate cultural value tied to time depth, monumentality, expert knowledge and aesthetics" (Smith, 2006, p. 299). The word 'authorized' indicates what, according to Smith, constitutes whether a particular site will be qualified as heritage or not. This dominant discourse "works to exclude, despite the intentions of individual practitioners, non-expert views about the nature and meaning of "heritage" (Smith, 2006, p. 299). As Smith also stresses, it works to constrain understandings of heritage as primarily material and also hinders productive and critical community engagements in heritage.

However, "there is not such thing as heritage" (Smith, 2006, pp. 13-16; Waterton, Smith, 2009). Heritage is not a 'thing' but it mainly refers to a set of attitudes to, and relationships with, the past (Harvey, 2001; Smith, 2006; Waterton, Smith, 2009). As Rodney Harrison (2013, p. 14) puts it: "these relationships are characterised by a reverence and attachment to select objects, places and practices that are thought to connect with the past in some way. The form this set of relationships takes varies both geographically and chronologically [...] but people must 'work' to produce these relationships". However, the most important is that heritage is formed in the present and reflects inherited and current concerns about the past (Graham, Howard, 2008, p. 1). Consequently, it ought to be perceived as a dynamic and nego- 
tiable process, subject to contestation and malleable to the needs of societies and cultures as well as identity requirements in the present (McDowell, 2008, pp. 49-50). In this way heritage should not only be equated with the past, but also considered as an important element of the present identity politics (Góral, 2016, pp. 56-57).

The literature on heritage is abundant (eg. Hewison, 1987; Lowenthal, 1996; Smith, 2004, 2006; Fairclough, Rodney, Jameson, Schofield, 2008; Kobyliński, 2009; Smith, Waterton, 2009; Meskell, 2012; Harrison, 2013; Macdonald, 2013; Logan, Nic Craith, Kockel, 2015). It conveys a range of concepts such as identity, power, place, memory, performance, community, amongst others (Smith, 2006, p. 48). The very important aspect is that of identity. Heritage and identity interact and build upon each other, not only on national scale but they are also undermined by regional, more local and even personal identities (Graham, Howard, 2008, p. 1, 8). By utilizing stories and material evidence, heritage may "represent or stand in for a sense of identity and belonging for particular individuals or groups" (Smith, 2006, p. 77), across the time and space of human history.

In this paper I incline towards understanding of heritage as a process by which people use the past (Smith, 2006, pp. 11-13). As Smith (2012) has stated: "heritage can be usefully understood as a subjective political negotiation of identity, place and memory; that it is a 'moment' or a process of re/constructing and negotiating cultural social values and meanings". In a similar vein, heritage is situated here as a cultural phenomenon that involves engagements with the past as a process of cultural production and as a social practice (Ashley, 2016, p. 554). It is understood as something that is 'done', rather something that is possessed or 'managed' (Smith, 2012; Harrison, 2013, p. 32).

As it has already been mentioned, heritage is a product of the present, being created in a continuous process of transformations (Kobyliński, 2013, p. 719). This statement has profound consequences not only for theory of heritage but it also has more practical implications. It follows, therefore, that heritage has less to do with tangible or intangible forms of the past than with the meanings placed upon them and the representations which are created from them (Graham, Howard, 2008, p. 2). According to this statement, contemporary discussions on heritage are often concerned with public access to it and often revolve around the multiplicity of stakeholders interested in it. Their vital part includes people or groups who perceive heritage as an opportunity to meet their own individual needs or to develop the entire community. Thus, widely accepted is the selective use of the past for contemporary purposes. Heritage is also selective in that it serves particular interests and political ideologies in the present (McDowell, 2008, p. 37, 42). The contents, interpretations and representations of the heritage resource are selected according to the demands of the present and shape the functions and meanings of heritage within any given group of community (Ashworth, Graham, Tunbridge, 2007). Thus, it shows that most heritage has little intrinsic values but they are placed upon heritage by people according to their present needs and aspirations. 
Abovementioned issues emerge from the critical heritage research tradition, which foregrounds heritage as a heterogeneous process that brings the perspectives of marginalised people and communities to the centre of debates about how heritage is defined and used (Ashley, 2016, p. 554). These issues have been further acknowledged in Convention on the Value of Cultural Heritage for Society signed in 2005 in Faro, that emphasizes the necessity to „take into consideration the value attached by each heritage comunity to the cultural heritage with which it identifies" (\$12a). Consequently, there is a need to investigate how and why the past and heritage are meaningful to different groups of people in the present (Holtorf, 2013, p. 80).

\section{THE MOUNT ŚLĘ̇̇A}

Ślęża is a mountain in the Sudetes foothills in Lower Silesia in southern Poland. Geomorphologically, the Massif of Ślęża forms a dome risen about 500 meters above the surrounding lowlands (fig. 1). The Ślęża Massif is mainly covered with forests. The solitary forested cone of the Mount Ślęża rises to $718 \mathrm{~m}$ above the surrounding open plain. From the south it adjoins to the second largest hill of the Ślęża Masiff, namely Radunia and from the north-eastern to Wieżyca hill. The etymology of the word Ślęża is perhaps derived from a Silesian word meaning "wet swampy place" (Matela, 2006, p. 178; Malinowska-Sypek, Sypek, Sukniewicz, 2010, p. 56). Its monolithic and massive silhouette is very well visible from the surrounding plains and during storms it concentrates thunder and lightning which even today attract human attention. This may be explained by the recently discovered deposits of titanium ore, unique in the world.

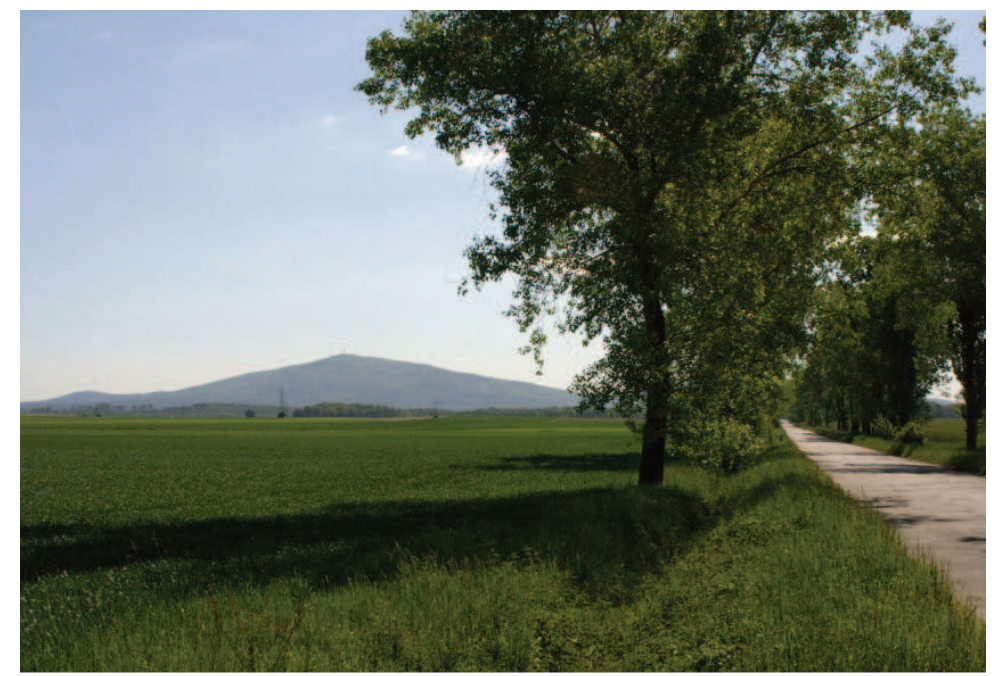

Fig. 1. Ślęża a view from the west 
The mountain and its surrounding region form the protected area called "Ślęża Landscape Park". It was established in 1988, covering an area of 81.90 square kilometers. It is a home to rare species of flora and fauna, for instance to about 370 species of spiders, including endangered ones. There are currently five reserves within the territory of the park, including The Mount Ślęża nature reserve, that is a landscape, geological and historical reserve. Its most precious elements include mosses, lichens and liverworts. The reserve also protects a very picturesque group of rock formations and their plant growth (Mikułowski, 1999; Rąkowski, 2002). On the top of a mount a tourist mountain lodge, an observation tower, a TV and radio mast, ruins of the medieval castle and the church of St. Mary, rebuild after the fire in 1851-1852, (fig. 2) are located. At the foot of the mountain there is a Będkowice Archaeological Reserve. It contains reconstructions of fences from the $8^{\text {th }}-11^{\text {th }}$ centuries and kurgan burial mounds from the $8^{\text {th }}-9^{\text {th }}$ centuries (Malinowska-Sypek, Sypek, Sukniewicz, 2010, pp. 32-33).

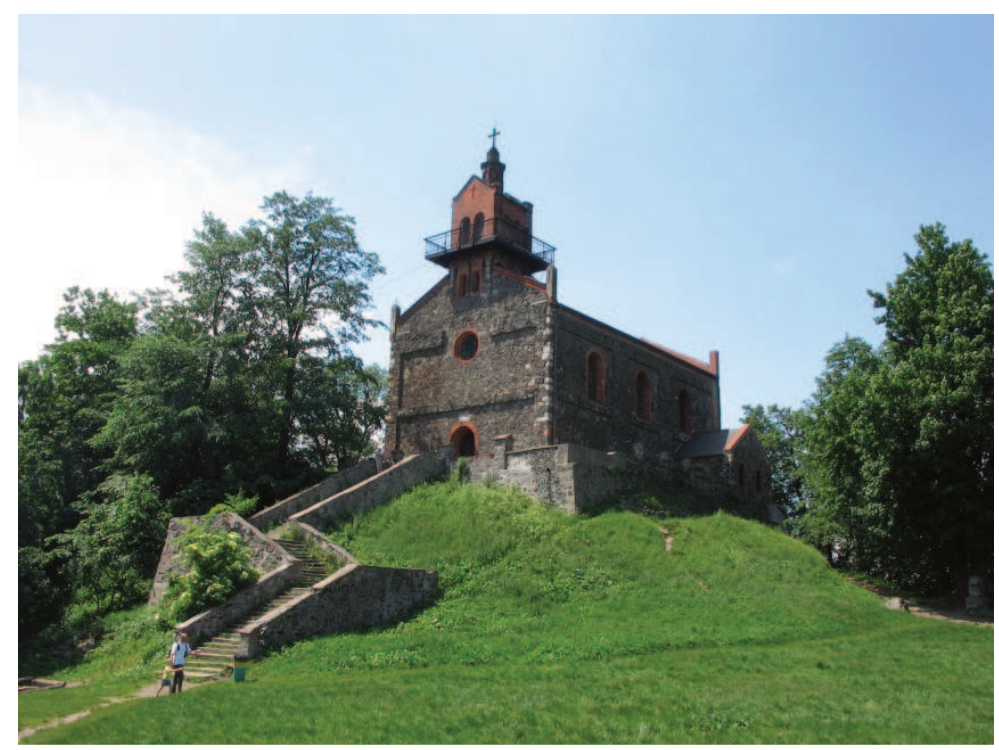

Fig. 2. St. Marys Church

The prehistory and history of Ślęża and different artefacts found on it have been extensively and thoroughly described in archaeological and historic literature, being a subject of diverse interpretations (see, e.g. Cehak-Hołubowiczowa, 1959; RosenPrzeworska, 1962, 1979; Korta, 1988; Słupecki, 1992, 1994; Gediga, 1995; Rosik, 2001; Domański, 2002; Woźniak, 2004; Mierzwiński, 2007). Due to its location Ślęża was probably a site of cult but it also played an important economic role for it provid- 
ed grazing for livestock and the natural resources to be found there - wood, stone, and metal ore - were exploited. The first traces of human activity on the Ślęża peak and lower down the massif date back to the Neolithic. At the turn of the Bronze and Iron Ages a Lusatian stronghold arose which was then destroyed by the Scythians around 500 B.C. The Mount was also inhabited by the Celts. The next documented period in Ślęża's history is from the $5^{\text {th }}$ century A. D. when there were stone quarries and millstone production took place (Domański, 2002). It is thought that a stronghold linked to pagan ceremonies was built on the peak in the $9^{\text {th }}$ century. It was later destroyed at the start of the following century. It is also known that in the first half of the $12^{\text {th }}$ century Piotr Włost, the then owner of Ślęża and palatine to Bolesław Krzywousty (Wrymouth), funded a monastery on the Mount and brought in monks from Flanders, who were to eradicate any remaining traces of its pagan past (Korta, 1988, pp. 283-306).

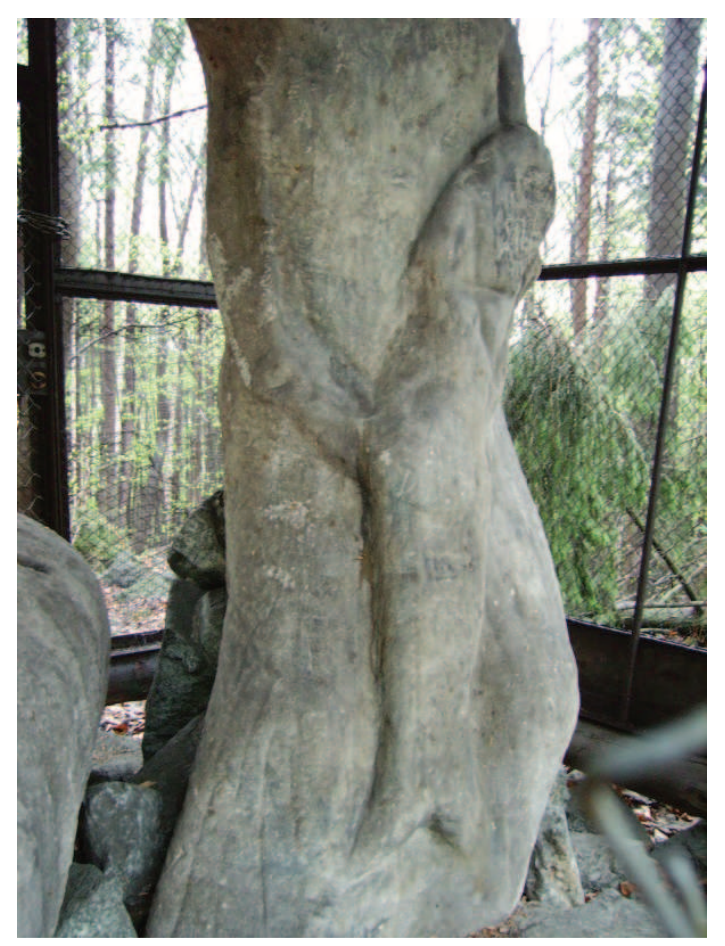

Fig. 3. A girl with fish

What deserves attention in the context of cult issues associated with the Mount Ślęża are the surviving stone walls surrounding the peak of the Mount Ślęża and the neighboring hills of Radunia and Wieżyca. An interpretation that these walls should be considered as sacred seems rather convincing, however, the question of their origin 
is still debatable among scientists (Leciejewicz, 1987, pp. 125-126; Korta, 1988, pp. 17-86). Additionally, numerous sculptures with mysterious markings of a diagonal cross and stone earthworks have been found on Ślęża Masiff and its nearness, including two she-bears, "a monk", "a mushroom" and "the girl with fish" (fig. 3). What seems certain is that these sculptures were carved out of a local stone, gabbro. Hovever, the interpretation of their cult meaning is still a matter of argument today. Also disputable is the function and chronology of the " $\mathrm{X}$ " sign the sculptures are inscribed with. Over time, they were attributed a vast number of possible origins and functions: from prehistoric solar symbols to medieval border posts, that were especially widespread in West Slavic territories (Leciejewicz, 1987, p. 126; Korta, 1988; Mierzwiński, 2007).

\section{THE MOUNT ŚLĘ̇̇A: CONTEMPORARY MEANINGS, CONTESTED VALUES}

However, the prehistory and history of Ślęża are not the only reasons for its ongoing popularity and the lively interest it attracts. Apart from the scientific debate there is another, ongoing public discussion, proving how important Ślęża is to many other people. Thus, I am interested here in not so much defining the significance or function of this site in the past, but rather interpreting its importance from the perspective of its contemporary functioning and how it is utilised by various stakeholders.

Today, the Ślęża Massif is relatively well developed in terms of tourism. Beauty spots, such as the Ślęża Landscape Park, and points of archaeological interest in the region draw in tourists and the mountain itself is the focus of developing cultural tourism (Malinowska-Sypek, Sypek, Sukniewicz, 2010, pp. 56-60). The area around Mount Ślęża has a dense network of ramblers', cycling, nature, educational, and archaeological walks. Tourist routes are relatively easy, scenic and well signposted. They usually run through woods and feature interesting relics of the past. Additionally, numerous cultural events take place in the surrounding area, such as festivals, open-air concerts and rallies. For example, in June in Sobótka there is organized an open-air "Festival of Slavs" that includes, amongst others, folk concerts, fairs, demonstrations of ancient handicrafts, or symposia on the history of Slavs. Quite popular is also an annual meeting held in the Ślęża Massif in Sulistrowiczki, namely "Harmony of the Universe". It is advertised as a "reunion of the people of a New Era" and it includes different events as concerts of gong and Tibetan singing bowls, workshops of alternative medicine, New Age alternative healing techniques, Ufo forum etc. Abovementioned initiatives, apart from their touristic aspects, are also significant for the economy of the area which relies on the tourist service industry and the promotion of the region.

Ślęża is also surrounded by many folk stories, tales and legends, which speak not only of the mysterious stone sculptures, but likewise of the rocks and even the 
caves (Sadebeck, 2008, 81-90). There are also legend originating not so far back in time, stories of a secret system of tunnels in the Ślęża massif in which, at the end of the Second World War, the Germans hid treasure (Góra, Maszkowski, 2007; Kowalski, Kudelski, 2009). These legends make this area more attractive for treasure and adventure seekers. Mount Ślęża also appears as an important literary theme. For example, in an apocalyptic science-fiction novel by Robert Szmidt "Apokalipsa według pana Jana" (2003), the Mount Ślęża and a secret system of tunnels in the Ślęża Massif are a place of refuge for the people of Wrocław after the nuclear war. Another book, namely "Ja, Dago Władca" (1990) by Polish famous writer Zbigniew Nienacki evokes the motif of pagan priests holding the mysterious rites on the top of Mount Ślęża. Significantly, in the literature, as well as in the common perception Ślęża functions as a mysterious mountain, where in ancient times pagan rites were celebrated or gathering of witches took place. The folklore surrounding Ślęża is thus a significant factor directly influencing understanding and perception of the past and present cultural landscape.

Futhermore, Mount Ślęża is usually considered to be a holy site of ancient pagan tribes. The most significant testimony of this are the words of Thietmar from Merseburg, bishop and chronicler, who in c. 1018 mentioned Ślęża as the object of veneration of all inhabitants of the country. He wrote: "This mountain was worshipped by all the townsmen for the reason of its enormity and its destiny as accursed pagan rituals were carried out over there" (Diethmar von Merseburg, 2002, p. 207). Nowadays, Ślęża, that represent an enormous time span can also serve as emotional foci not only for collective, mainly local, but also for individual identities. Among them those inspired by the ideology of New Age or neopaganism predominate, and many visitors invoke tribal rituals or resurrect forgotten traditions (Harpula, 2009). They are good examples of the emergence of new religious movements, the current return to pre-Christian traditions and maintaining a link with the ancestors of these lands. It constitutes an important element of modern Polish pagan movement, namely "native faith", united around Rodzimy Kościół Polski ("the Native Polish Church"1) or Zachodniosłowiański Związek Wyznaniowy "Słowiańska Wiara" ("The Western Slavic Religious Association 'Slavic Church"2»). Neopagans often refer to Ślęża as a place where pagan rituals were carried out, and they reconstruct and attempt to resurrect pagan traditions. For them, Ślęża is a sacred site, an important centre for prehistoric pagan cults. Pagan meetings held on the peak of the mountain aim to celebrate the pagan world, the cycles of sowing and reaping, the passage from Winter to Spring (21st of March), then to Summer and Autumn, to honour and "resurrect the gods of Slavs" or to honour the forces of Nature. Every year on the night of 21 to 22 June the native faith followers of Slavic deities are gathering at Ślęża to celebrate

\footnotetext{
${ }^{1}$ See: http://www.rkp.org. pl/ Accessed January 3, 2017.

${ }^{2}$ See: http://www.slowianskawiara.pl/ Accessed January 3, 2017.
} 
Midsummer Night, its biggest holiday associated with the summer solstice (fig. 4). Ślęża is also an ideal place to celebrate important events in people's lives: marriages (swadźba) and other rites of passage. To validate their visions and reconstructions of a pagan religion system of Slavs a wide symbolism is used here, as for example the cult meaning of slanted crosses engraved on sculptures or stone pillars, stone walls surrounding the peak of Mount Ślęża or "sacred spring" flowing out of the mountain. All these evidence is considered as an unquestionable proof of an existence of a centre of a pagan solar cult on Ślęża in prehistory and that its cult meaning is continuing to the present time.

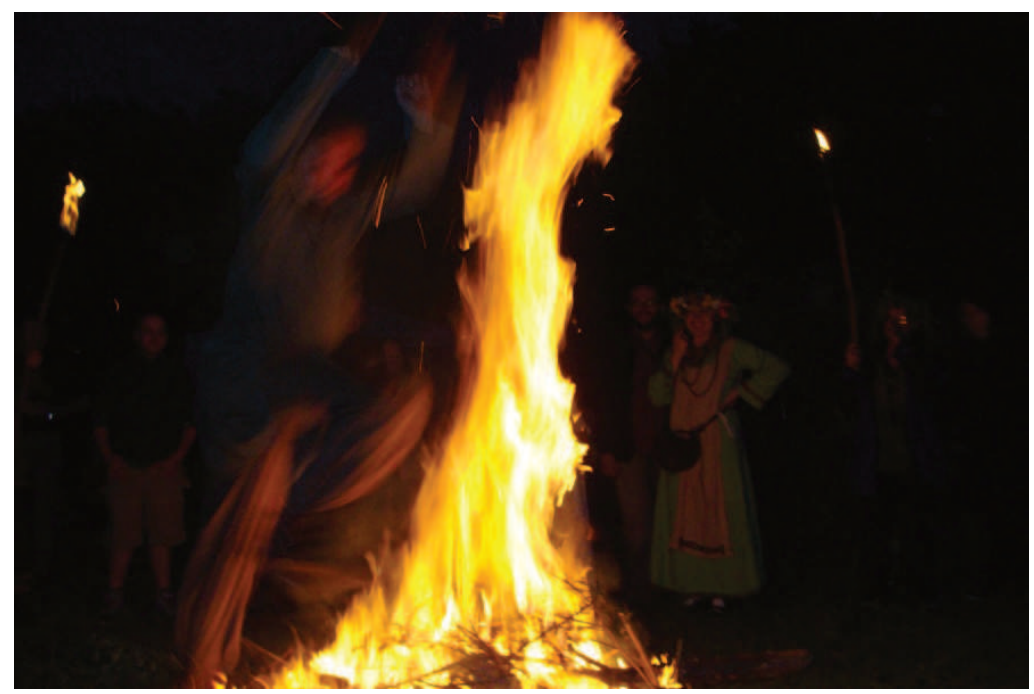

Fig. 4. Jump over a fire

Nationalists have also chosen the site as a symbol of Slav strength. They hold meetings here and run training camps in the forests nearby. The "Zadruga" group is one such example. As active Neopagans they began by developing rituals, including the ritual of the first haircut, performed for the first time on Mount Ślęża in 1987 (Marszewski, 2006). Their ideology is a mix of anti-Christian and nationalist ideals, referring to the native culture and beliefs, focusing on the leading notions of blood and land. For example, in 2009 on the top of Ślęża they organized the celebration of the harvest festival of Polish neopagans "Feast in honor of the Polish Land - Crops 2009 Ślęża". We can read (my translation) "We, Poles, are tied with a special bond with this Land in which our roots are deeply ingrained - the bond of love, pride and loyalty. It is this Land that feeds us today, as it used to fed generations of our ancestors; here our children come to the world. Native land, the Mother of our Nation, our 
home, our treasure and honor of the Polish world [...]. Here is our place, here is our heritage, here is our Faith and Culture" ${ }^{3}$. Thus, this somewhat imagined past is becoming a crucial element in the issue of identity, although in this particular case along with rejecting Christian traditions really dangerous connotations to racist ideas can be observed. It is instrumentally used in a selective manner by some groups of people as a proof of "Slavicness" or purely "Polish character" of the Mount Ślęża to validate and legitimate particular ideology.

The Ślęża Massif also attracts seekers of spiritual truth, esotericists and enthusiasts of ancient cultures. The mountain is generally believed to emanate some mysterious energy. Many people who visit Śleża and its vicinity are attracted by the mystery and atmosphere which surrounds it. Many people view Ślęża as one of the key "chakram" locations in Poland. They claim it is a sacred place that embody the magical powers of nature (see, e.g. Matela, 2006, pp. 177-184; 2009, pp. 112-125). A number of people can prove the existence of the Earth's force fields by direct experience. Dowsers who visit this site say the mount is a strong energy sources and furthermore claim that it could have functioned in prehistoric times as signpost directing people to such sources of energy. There is a connection here to the famous ley lines, that is energy paths between powerful points on Earth (Matela, 2006, pp. 181-182; 2009, p. 123). There is also a widespread belief that The Mount Ślęża is a site where one can sense the underlying powers of nature. The current belief amongst dowsers is that it is a source of unidentified energy which has a positive effect on the human psyche and body, and it has healing powers: many people do in fact visit Ślęża for this very reason: to "charge themselves up with energy" or to find help in healing from emotional, mental or even physical disturbances.

The significance of Ślęża is also important in other contexts. Some believe that it is a navigational marker and landing site for visitors from outer space (see Matela, 2006, p. 177). Ślęża, due to its singularity, has also been a point of reference for religious sects, such as "the Antrovis Association for the Rebirth of People and the Earth", registered in Wrocław in mid-1990 (Paleczny, 1998, pp. 175-177; Simpson, 2000, pp. 139-140). This sect offered some predictions, for example that many people would contract terrifying skin disease from space radiation and that in 1999 a group of "chosen people" (precisely 144,000 Slavs, mainly Poles) "would be picked up on Mount Śleża near Wrocław and flown in spaceships to the distant planet of Mirinda" (Ramet, 1998, p. 324).

The mount also forms an essential element in the pseudo-archaeological "Project Cheops", with the financial support from the Foundation "Dar Światowida", found-

${ }^{3}$ Quoted from: http://ns-zadruga.blogspot.com/2009_09_19_archive.html Accessed January 3, 2017.

${ }^{4}$ See: http://www.projekt-cheops.com/plain.aspx?languageId=22\&menuId=62\&sectionId=230\&cmd= Accessed January 3, 2017. 
ed in 2001 in Chicago. Its aim was to save the world from a predicted final catastrophe in December 2012 (Beźnic, 2011; Wójcikiewicz, 2012). The initial objectives of the Cheops project was to bring about archaeological excavations in Egypt for the purpose of unearthing the Great Labyrinth as described by Herodotus, and the tomb of the Pharaoh known as the Builder of the Great Pyramid (Cheops). The information about the location of both objects have been provided by the "medium", namely Ms Lucyna Łobos. In 2004 and 2005 archaeological excavations were carried out beneath the floor of the nineteenth-century church located at the top of the mountain which were meant to verify messages passed on via the "medium". According to an agreement, they were carried out by the staff of Department of Archaeology, University of Wrocław, Poland. The official position of Polish archaeology at that time was that the church stands on solid rock. After removing the floor, it turned out that the church was built on the ruins of the fourteenth-century castle. Within two seasons, the excavations discovered old walls of the castle and a number of rooms (Wójcikiewicz, 2012, pp. 47-58). Moreover, GPR survey revealed anomalies that suggested the existence of shafts and chambers at lower levels, which required further investigation. In 2006 the Wrocław Diocese did not extend permission to continue excavations. Until now, despite the express written willingness of the Foundation to fund further research, no new works have been done at this site. However, Foundation, as one can know from their official stand expressed on the project website, is still ready to help financially to install floor in the church situated on the top of the Mount Ślęża.

\section{MOUNT ŚLĘ̇̇A AS A SITE OF MEMORY}

The essence of the concept of "sites of memory" and the way of their investigations as proposed by Nora does not consist in the fact that they describe the past meaning or perception of particular sites, but mostly in their present significance. Thus, this perspective enables to perceive some historical phenomena from the point of view of how they function in the collective memories, which pays our attention to the ways of constructing, transmitting, commemorating, erasing and manipulating of images of the past as well as some collective ideas about it (Kończal, 2008, p. 172). The investigation of "sites of memory" may raise a number of questions concerning for example, why certain sites have a special meaning for some groups of people, the meanings attributed to particular sites or the differences in their understanding and conceptualization that result from different collective memories of people.

Mount Ślęża, as a focal point for the collective imaginarium, provides the arena for the manifestation of various types of behaviour and different interpretations and can be the subject of "palimpsest reading" (Woźny, 2012, pp. 168-170). As we 
could see, it has attained an accepted place in social consciousness because of its aesthetic and landscape values, as well as its atmosphere of mystery (Marciniak, 1994, p. 141). Thus, it may be significant not only from a scientific point of view but is important to many people for other reasons, some may have purely pragmatic reasons (archaeologists), others aesthetic (tourists) and yet others spiritual (dowsers, esotericists). As it was already said, Nora claimed, that lieux de mémoire are lieux in three senses of the word, namely material, symbolic, and functional. Let me take a closer look at these three meanings of sites of memory.

The material aspect of sites of memory includes natural, concretely experienced lieux de mémoire - such as cemeteries, museums etc. The focus is on the tangible, material aspect upon which how they are perceived as a particular place or space is founded. As such, a site of memory exists topographically, "a monumental site of memory", due to the characteristics of its location and the fact that it is literally rooted in the earth. In this way Ślęża can be viewed through the prism of topography. Ślęża, together with its cultural relics possesses a material dimension through concrete, physical references. It is the most tangible, clear and obvious aspect though not necessarily the most dominant in the case of sites of memory.

There is also a symbolic dimension to sites of memory, according to Nora (1989, p. 19) "by referring to events and experiences shared by a small minority, it [a site of memory] characterises the identity of a larger group which may not have participated in them". This is about, amongst others, how dominant or subordinate lieux de mémoire are presented. Some interpretations are spectacular, in themselves imposing or imposed upon us, in other words, the official (scientific) version: sites which are to be admired and visited. On the other hand, we are dealing with all sorts of alternative interpretations, which are to be found beyond the official discourse. In the case of Ślęża it is possible to include: esotericists, bio-energy healers, diviners, pseudoarchaeologists and mystics whose opinions are excluded from the official discourse. The attitudes of archaeologists towards other theories on Ślęża's role and function, different interpretations and the activities of certain groups of people is rather sceptical or negative, different opinions and attitudes are not taken seriously.

And finally, the functional aspect of sites of memory includes a whole range of approaches to Ślęża revealing the usefulness of the past and its sometimes instrumental exploitation for a particular purpose. The functionality of a site of memory signifies that it fulfils practical functions, it is something which can be described as the practical past (memory), used by various groups for specific, present aims, where the aforementioned reference to the past carries significant meaning for the present functioning of certain collectives (White, 2009, p. 15). In this context it is also possible to place the paradigm of the preservation of Ślęża as an element of archaeological heritage and also the popularisation of knowledge about the past of Mount Ślęża.

It can be claimed that Mount Ślęża as the "lieu of mémoire is double: a site of excess closed upon itself, concentrated in its own name, but also forever open to the 
full range of its possible significations" (Nora, 1989, p. 24). The Mount Ślęża can be perceived as a concrete, physical (material) site, located in a definite and physically experienced space, but also as an abstract, imagined site, as well as symbolic or functional one. It allows to put forward few more general conclusions. regarding the investigation of heritage sites as sites of memory. First, it shows the variability of meanings ascribed today by various groups of people to prehistoric monuments and heritage sites. The importance attributed to them is not constant but may undergo a process of ongoing re-signification. As such, these sites are not a once and for all defined entities, but rather form a part of a dynamic real, social or cultural imagined space. They constitute significant sites which have been invested with meaning, often representing the 'heritage' of a particular individual, group or community. What is also symptomatic, it is a testimony of a current use of the past by modern communities and groups who "need a record of prior experience and require a narrative of the past which serves to explain or justify their present, often at the cost of historical accuracy" (McDowell, 2008, p. 38, p. 42).

Second, heritage sites as sites of memory may have been attributed with provisional and thus contested and often disputed values. This is demonstrated by mutually exclusive interpretations and views on Ślęża's role and functions in the past as well as by present attitudes towards it. It shows the ways memory of this mountain may and in fact do function in the human collective consciousness. This case exemplify that such locations have no fixed memories ascribed to them but rather we observe here a dynamic, shifting memory that is continuously produced rather then merely confined within demarcated sites as well as an emergence of a multiple pasts and a continual remaking of memorial sites.

Third, heritage sites may be valued not only for a purely scientific reasons but be regarded by some groups of people as the core of the process of their selfidentification. Places that people for different reasons identify themselves with may create a sense of identity, belonging or relationship between people. From such a perspective heritage is not valued for its literal, but for its metaphorical content, that is, the stories it evokes about the present. Such stories - as Cornelius Holtorf (2014, p. 3361) claims - "may manifest belonging through symbolic references of heritage to a common past suggesting a shared collective identity; or they may describe alternative ways of life which can stimulate audiences in the process of reconsidering their own lives".

And last, essential in this context seems to be the "ownership" of sites of memory: it may be understood literally, as a physical possibility to visit or see certain sites by some people, but also more metaphorically as an ability to refer to them as an integral part of one's own past (Szpociński, 2008, p. 15). Sites of memory, both real and imagined ones, embody some values and ideas, important from the point of view of a given individual or community. An unavoidable conflict about the ownership of heritage when the opposing sides aim at exclusive rights to the substance of objects can not easily be resolved. The criterion for resolving this conflict 
should be ethical, rather than legal or political. In such a context Zbigniew Kobyliński (2013, p. 723) proposes an idea of the adoption of the principle of free access to cultural heritage. It means that heritage ought to be regarded as a public domain, to which all members of society must have access, which they have the right to use in any and every non-destructive way and for which they also are all equally responsible. Moreover, the use by people of the value of cultural heritage cannot confine rights of other individuals and groups, and therefore it is necessary to control the public uses of cultural heritage, what should apply to everyone, including archaeologists and heritage professionals.

\section{TOWARDS A DIALOGUE}

As different attitudes to the Mount Ślęża outside the academic discourse has shown, there is an obvious clash between these interpretations and attitudes on many levels that seems to relate mainly to the meaning and function of heritage sites in the present. The Mount Ślęża is not an exception in this regard as there are many other heritage contested sites, in Poland and worldwide as seen in case of Stonehenge (Bender, 1998), stone circles in Pomerania, Poland (Pawleta, 2012), heritage in South Africa (Meskell, 2012), pagan engagements with archaeological monuments in the UK (Blain, Wallis, 2007), or in recognition of legitimate interest of Native Americans in the USA (e.g. Chari, Lavallee, 2013). These examples reveal a vast array of actors and stakeholders interested in heritage for many reasons. Simulatenously, they also expose imbalances between professionals and communities in relation to the control of resources, narratives, interpretation and meaning in favour of professional attitudes, what is characteristic to the authorized heritage discourse.

Archaeologists and heritage professionals can define and interpret past meanings of heritage, but they cannot solely determine its relevance to people in the present day and their contemporary significance. By rejecting any alternative discourses, they not only enforce one scientific vision of the past along with the preservation ethos, but also negate any differing attitudes to the past that people can have and reject that it may play an important role in a number of social and personal issues crucial for people today such as identity, spirituality, sociality and so on. It is not the intention of this paper to suggest that some alternative approaches should hold a privileged position over archaeological or other approaches, nor that all interpretations are equally good or desirable (e. g. racist ones), but we avoid slipping into a nihilistic relativism by seeking conversations with those with whom we disagree, still expressing our own voices and opinions (McDavid, 2009, p. 226). However, it is to stress in this context that archaeological interpretation and attitudes are only one issue on the heritage agenda there is a need to recognise its multidimensional value, not only as a source of knowledge available to scientists or as places in need 
of protection for future generations, but also as an element of collective ownership that should serve the needs of the living.

It is neither an easy nor sometimes even a possible task to find a balance between different interpretations of the Mount Ślęża and the approaches to it. In searching for an option which will enable different opinions to be reconciled I would refer to Mikhail Bakhtin's (1986) polyphonic dialogue and the concept of many voices in the approach to the past and heritage. For Bakhtin, dialogue which occurs only through engagement with another invites us to understand the other's specificity as fully as possible. The key concepts of Bakhtin's dialogue are heteroglossia and polyphony. Heteroglossia should be understood as a multiple-voiced language, which is a language of different social groups (professionals, nonprofessionals etc.), and polyphony as the existence of many different voices. Generally, the idea is that dialogue moves forward to a consensus, but the goal that Bakhtin endorses is not a consensus. On the contrary, dialogue escapes a definite finalisation by existing on the threshold of several interacting viewpoints and it is their separateness and irreducible standpoints that are essential to the dialogue. Even when they agree, as they may, they do so from different perspectives and different senses of the world.

Such a dialogue is not about unifying opinions or research approaches, but the acceptance of the coexistence of their number and diversity. Dialogue between different stakeholders is mainly of greater interest to archaeologists and heritage managers for a number of reasons: (1) dialogue, in which particular standpoints and opinions are articulated, creates the opportunity to identify which interpretations are unsuitable or unacceptable and why, or in the light of which arguments they should be rejected; (2) dialogue enables the practical realisation of the idea of heritage as common property, its management and how it can be utilised, highlighting common responsibility for its protection, benefiting both heritage and society; (3) being open to dialogue is ultimately an indication of archaeology's self-awareness and a chance for the discipline to understand and define its role in a changing world and to open up new perspectives for theoretical reflection and practical activities. It is also a question of ethics, not to treat one's own point of view as the only correct interpretation possible, but to see the benefits which other approaches and alternative opinions can bring.

Thus, heritage professionals and archaeologists should actively engage the multiple stakeholders and take seriously the stories about the present that are told through the cultural heritage. Consequently, different stakeholders should be listened to and their preferences be respected in pragmatic, pluralistic and open-ended dialogue, even though not everybody may possess relevant specialist expertise and professional experience (Holtorf, 2013, p. 69; 2014, p. 3361). Such a dialogue concerning heritage should be based on a fundamental aim of any cultural heritage management, namely the principle of free and common access to the cultural heritage and entail the public right to decide about activities directed at cultural heritage, to its perception and interpretation (Kobyliński, 2013, pp. 722-723). It would help 
to understand more about different communities and stakeholders priorities regarding both past and present and to "work out solutions which would be favourable - or at least acceptable - for different interested groups and individuals" (Kobyliński, 2013, p. 723). Moreover, engagement in self-conscious and explicit collaborations and interactions would facilitate meaningful community partnerships and help to conduct community archaeology in a dialogical way that involves different stakeholders as equal partners (Sørensen, Carman, 2009, p. 7; Smith, 2012).

\section{CONCLUDING REMARKS}

To conclude, as I attempted to show, based on this example of Mount Ślęża, the concept of "sites of memory" can aid research into the presence of heritage sites in the present, especially from the angle of how they function in society, the diverse aims which they fulfil and the narratives created around them by different groups of people. Thus, this category permits reference to issues of the social functioning and significance of Mount Ślęża, whose current role does not emerge only from the role it played in the past but above all from how it is used in contemporary times. This example shows that heritage not only is tied to people's sense of identity, but it is also an inherent part of the heritage process people remember the past in the light of their present needs and aspirations (McDowell, 2008, p. 42).

However, it is difficult to expect any agreement between different discourses which have emerged on Ślęża due to their inconsistency. They do show, however, Ślęża as a place which is alive, where many discourses are interwoven or where the past is still being created anew. In the case of Mount Ślęża the variety of opinions do not interconnect nor do they form any order, they have their own integrity, independence and inconsistent distinctions. These "alternative" discourses function and will continue to function independently of archaeological and heritage professionals ascertainments, whether they like it or not. Not being in possession of an effective remedy to such a situation, I have proposed a Bachtin's postulate of dialogue which does not aim for a consensus, but rather highlights heterogeneity, ambiguity or obscurity. It is about the attempt to understand the "alternative" discourses, being conscious that not all of them are commensurate, correct nor even desired. Yet, in order to evaluate this situation archaeologists and heritage professionals need to be constructive, professional, open to dialogue and social expectations.

\section{ACKNOWLEDGEMENTS}

This paper has benefited from the financial assistance afforded by the European Comision for a project entitled „NEARCH. A new scenarios for a communityinvolved archaeology". Although this publication resulted from the project support- 
ed by the European Commission, it reflects the view of its author, exclusively, and the Commission should not be held responsible for any use which may be made of information and opinion presented herein. Any errors or misinterpretations are entirely the responsibility of the author.

\section{REFERENCES}

Ashley S. L.

2016 Acts of Heritage, Acts of Value: Memorialising at the Chattri Indian Memorial, UK. International Journal of Heritage Studies, 22(7), pp. 554-567.

Ashworth G. J., Graham B. J., Tunbridge J. E.

2007 Pluralising Pasts: Heritage, Identity and Place in Multicultural Societies. London: Pluto.

Assman J.

2008 Pamięć kulturowa. Pismo, zapamiętywanie i polityczna tożsamość w cywilizacjach starożytnych. Warszawa: Wydawnictwa Uniwersytetu Warszawskiego.

Bachtin M.

1983 Bachtin. Dialog, język, literatura. Warszawa: Państwowe Wydawnictwo Naukowe.

Bender B.

1998 Stonehenge. Making Space. Oxford: Berg.

Beźnic S.

2011 Skarby Ślęży w katastroficznym scenariuszu końca świata w 2012 roku. In: W. Kunicki, J. Smereka (eds.), Ślężańskie światy (pp. 169-190). Wrocław: Oficyna Wydawnicza ATUT.

Blain J., Wallis R.

2007 Sacred Sites, Contested Rites/Rights. Pagan Engagements with Archaeological Monuments. Brighton, Portland: Sussex University Press.

Cehak-Hołubowiczowa $\mathrm{H}$.

1953 Śląski Olimp. In: E. Melczyńska (ed.), Szkice z dziejów Ślaska (vol. 1, pp. 1-18). Warszawa: Książka i Wiedza.

Cehak-Hołubowiczowa $\mathrm{H}$.

1959 Kamienne kręgi kultowe na Raduni i Ślęży. Archeologia Polski, 3, pp. 51-100.

Chari S., Lavallee J. M. N. (eds.)

2013 Accomplishing NAGPRA. Perspectives on the Intent, Impact, and Future of the Native American Graves Protection and Repatriation Act. Corvallis: Oregon State University Press.

Connerton P.

1989 How Societies Remember. Cambridge: Cambridge University Press.

Diethmar von Merseburg

2002 Kronika Tietmara. Kraków: Universitas.

Domański G.

2002 Ślęża w pradziejach i średniowieczu. Wrocław: Instytut Archeologii i Etnologii PAN Oddział we Wroclawiu. 
Fairclough G., Harrison R., Jameson J. H., Schofield J. (eds.)

2008 The Heritage Reader. New York: Routledge.

Gediga B.

1995 Bemerkungen über die monumentalne Steinskulpturen aus der Legend Ślężaberg/ Zobten in Schleisen. Pravěk, 5, pp. 189-202.

Góra G., Maszkowski P.

2007 Tajemnice Ślęży. Odkrywca, 7(102), pp. 10-13.

Góral A.

2015 Cultural Heritage as a Shared Resource. The Role of Collaboration Between Stakeholders in Cultural Heritage Management. In: Ł. Gaweł, E. Kocój (eds.), Cultural Heritage: Management, Identity and Potential (s. 55-65). Kraków: Jagiellonian University Press.

Graham B., Howard P.

2008 Heritage and Identity. In: B. Graham, P. Howard (eds.), The Ashgate Research Companion to Heritage and Identity (pp. 1-15). Aldershot: Ashgate Publishing Limited.

Halbwachs M.

1969 Społeczne ramy pamięci. Warszwa: Państwowe Wydawnictwo Naukowe.

Harpula W.

2009 Wskrzeszają bogów Stowian. Downloaded from: http://wiadomosci.onet.pl/prasa/wskrze szaja-bogow-slowian /9t7pdf. Accessed January, 3, 2017.

Harrison R.

2013 Heritage. Critical Approaches. London: Routledge.

Harvey D. C.

2001 Heritage Pasts and Heritage Presents: Temporality, Meaning and the Scope of Heritage Studies. International Journal of Heritage Studies, 7(4), pp. 319-338.

Hewison R.

1987 The Heritage Industry: Britain in a Climate of Decline. London: Methuen.

Holtorf C.

2013 The Past People Want : Heritage for the Majority? In: G. Scarre, R. Coningham (eds.), Appropriating the Past: Philosophical Perspectives on the Practice of Archaeology (pp. 63-81). Cambridge: Cambridge University Press.

Holtorf C.

2014 Heritage: Public Perception. In: C. Smith (ed.), The Encyclopedia of Global Archaeology (pp. 3361-3366). New York: Springer.

Kobyliński Z.

2009 Wtasność dziedzictwa kulturowego. Warszawa: Instytut Archeologii i Etnologii PAN.

Kobyliński Z.

2013 Cultural Heritage: Values and Ownership. In: S. Bergerbrant, S. Sabatini (eds.), Counterpoint: Essays in Archaeology and Heritage Studies in Honour of Professor Kristian Kristiansen (pp. 719-724). Oxford: Archaeopress.

Kończal K.

2008 Co dwa stopnie to nie jeden. Kronika (nie)obecności ,miejsc pamięci” w badaniach historycznych. Zapiski Historyczne, 78(2-3), pp. 171-189. 
Kończal K.

2009 Bliskie spotkania z historią drugiego stopnia. In: A. Szpociński (red.), Pamięć zbiorowa jako czynnik integracji i źródto konfliktów (pp. 207-226). Warszawa: Wydawnictwo Naukowe Scholar.

Korta W.

1988 Tajemnice góry Ślęży. Katowice: Śląski Instytut Naukowy.

Kowalski J. M., Kudelski R. J.

2009 Złoto generałów. Stużby specjalne PRL na tropie skarbów III Rzeszy. Kraków: Octopus Centre.

Leciejewicz L.

1987 In pago Silensi, vocabulo hoc a quodam monte... sibi Indio": o funkcji miejsc kultu pogańskiego w systemie politycznym Słowian zachodnich doby plemiennej. Śląski Kwartalnik Historyczny Sobótka, 42(2), pp. 125-136.

Logan W., Nic Craith M., Kockel U. (eds.)

2015 A Companion to Heritage Studies. Malden: Wiley-Blackwell.

Lowenthal D.

1996 The Heritage Crusade and the Spoils of History. Cambridge: Cambridge University Press.

Malinowska-Sypek A., Sypek R., Sukniewicz D.

2010 Przewodnik archeologiczny po Polsce. Warszawa: Wydawnictwo Arkady.

Marciniak K.

1994 The Perception and Treatment of Prehistoric and Contemporary Sacred Places and Sites in Poland. In: D. Carmichael, J. Hubert, B. Reeves, A Schanche (eds.), Sacred Sites, Sacred Places (pp. 140-151). New York: Routledge.

Marszewski M.

2006 Nacjonalizm „Zadrugi” jako przykład nacjonalizmu niechrześcijańskiego. Downloaded from: http://www.etnologia.pl/multi-kulti/teksty/nacjonalizm-zadrugi-jako-przyklad-na cjonalizmu-niechrzescijanskiego.php Accessed January, 3, 2017.

Macdonald $\mathrm{S}$.

2013 Memorylands: Heritage and Identity in Europe Today. London: Routledge.

Matela L.

2006 Tajemnice Stowian. Poznaj sekrety słowiańskich przodków. Białystok: Studio Astropsychologii.

Matela L.

2009 Polska magiczna. Przewodnik po miejscach mocy. Białystok: Studio Astropsychologii.

McDavid C.

2009 The Public Archaeology of African America. Reflections on Pragmatic Methods and Their Results. In: M. L. S. Sørensen, J. Carman (eds.), Heritage Studies. Methods and Approaches (pp. 217-234). London - New York: Routledge.

McDowell S.

2008 Heritage, Memory and Identity. In: B. Graham, P. Howard (eds.), The Ashgate Research Companion to Heritage and Identity (pp. 37-53). Aldershot: Ashgate Publishing Limited.

Meskell L.

2012 The Nature of Heritage. The New South Africa. Malden: Willey-Blackwell. 
Mikułowski B.

1999 Ślężański park krajobrazowy jako obszar chroniony i turystyczny. In: J. Wyrzykowski (ed.), Turystyka alternatywna jako wazny czynnik rozwoju turystyki przyjazdowej w Europie Środkowej i Wschodniej (pp. 123-130). Wrocław: Instytut Geografii Uniwersytetu Wrocławskiego.

Mierzwiński A.

2007 Ślężańska układanka. Strukturalno-semiotyczne poszukiwania kontekstu historycznego. Wrocław: Wydawnictwo Chronicon.

Nienacki Z.

$1990 \quad J a$, Dago, Władca. Olsztyn: Pojezierze.

Nora P.

1989 Between History and Memory: les lieux de mémoire. Representation, 26, pp. 7-24.

Paleczny T.

1998 Sekty. W poszukiwaniu utraconego raju. Kraków: Nomos.

Pawleta M.

2012 The Past in the Present. A Case of Ancient Stone Rings in Pomerania, Poland. In: N. Schücker (ed.), Integrating Archaeology - Science, Wish, Reality (pp. 9-16). Frankfurt: Römisch-Germanische Kommission.

Ramet S. P.

1998 Nihil Obstat: Religion, Politics and Social Change in East Central Europe and Russia. Durham: Duke University Press.

Rąkowski G. (ed.)

2002 Parki krajobrazowe w Polsce. Warszawa: Instytut Ochrony Środowiska.

Rosen-Przeworska J.

1962 Les sculptures de Ślęża et problème celtique en Pologne. Warszawa: Państwowe Wydawnictwo Naukowe.

Rosen-Przeworska J.

1979 Spadek po Celtach. Wrocław: Zakład Narodowy im. Ossolińskich.

Rosik S.

2001 W cieniu „Śląskiego Olimpu”... Uwagi nad możliwością kosmicznej waloryzacji góry Ślęży w badaniach nad historią religii. In: S. Rosik, P. Wiszewski (eds.), Origines mundi, gentium et civitatum (pp. 62-72). Wrocław: Wydawnictwo Uniwersytetu Wrocławskiego.

Sadebeck M.

2008 Góra Ślęża i jej okolice. Wrocław: Oficyna Wydawnicza ATUT.

Simpson S.

$2000 \quad$ Native Faith. Polish Neo-Paganism at the Brink of the 21st Century. Kraków: Nomos.

Słupecki L.

1992 Ślęża, Radunia, Wieżyca. Miejsca kultu słowiańskiego w średniowieczu. Kwartalnik Historyczny, 99(2), pp. 3-15.

Słupecki L.

1994 Slavonic Pagan Sanctuaries. Warszawa: Institute of Archeology and Ethnology, Polish Academy of Sciences. 
Smith L.

2004 Archaeological Theory and the Politics of Cultural Heritage. London, New York: Routledge.

Smith L.

$2006 \quad$ Uses of Heritage. London, New York: Routledge.

Smith L.

2012 Discourses of Heritage: Implications for Archaeological Community Practice. Nuevo mundo mundos nuevos: nиеvomundo. DOI: 10.4000/nuevomundo.64148

Smith L., Waterton E.

2009 Heritage, Communities and Archaeology. London, New York: Bloomsbury Academic.

Sørensen M. L. S., Carman J.

2009 Introduction. Making the Means Transparent: Reasons and Reflections”. In: M. L. S. Sørensen, Carman J. (eds.), Heritage Studies. Methods and Approaches (pp. 3-10). London, New York: Routledge.

Szafrański W.

1979 Pradzieje religii $w$ Polsce. Warszawa: Iskry.

Szmidt R.

2003 Apokalipsa wedtug pana Jana. Katowice: Rebis.

Szpociński A.

2008 Miejsca pamięci (lieux de mémoire). Teksty Drugie, 4, pp. 11-20.

Waterton E., Smith L.

2009 There is not Such Thing as Heritage. In: E. Waterton, L. Smith (eds.), Taking Archaeology out of Heritage (pp. 10-27). Cambridge: Cambridge Scholars Publishing.

Wesołowski J.

2009 Ślęża - oczyma mediów. Czwarty Wymiar, 11, pp. 32-35.

White $\mathrm{H}$.

2009 Proza historyczna. Kraków: Universitas.

Woźniak Z.

2004 Problem istnienia celtyckiego nemetonu na Ślęży. Przegląd Archeologiczny, 52, pp. 131-183.

Woźny J.

2012 Palimpsestowa natura pradziejowych miejsc kultowych. In: B. Gediga, A. Grossman, W. Piotrowski (eds.), Rytm przemian kulturowych $w$ pradziejach $i$ średniowieczu (pp. 165-176). Biskupin, Wrocław: Muzeum Archeologiczne, Polska Akademia Nauk.

Wójcikiewicz A.

2011 W poszukiwaniu wielkiego labiryntu. Egipt, archeologia i rok 2012. Katowice: Wydawnictwo KOS.

Zalewska A.

2012 Academic Constructs About the Past and Early Education as (Dis)entangled Components of Identity Formation Processes. In: A. Simandiraki-Grimshaw, E. Stefanou (eds.), From Archaeology to Archaeologies: the 'Other' Past (pp. 56-66). Oxford: British Archaeological Reports International Series. 


\section{PRZESZŁOŚĆ WE WSPÓŁCZESNOŚCI: GÓRA ŚLĘŻA W KONCEPCJI „MIEJSC PAMIĘCI” (LIEUX DE MÉMOIRE) PIERRE'A NORY}

\section{Streszczenie}

Celem artykułu jest analiza społecznego znaczenia miejsc zabytkowych dla różnych grup ludzi we współczesnej Polsce. Punktem moich odniesień będzie góra Ślęża. Dyskusja na temat jej funkcji i znaczenia w przeszłości prowadzona jest od dawna, przede wszystkim przez archeologów i historyków. Jednak równolegle do rozważań naukowych toczy się na ten temat dyskurs potoczny, który świadczy o jej ważnej roli, jaką odgrywa ona w życiu ludzi niezajmujących się zawodowo zamierzchłą przeszłością.

Góra Ślęża, określana „Śląskim Olimpem”, stanowi poniekąd miejsce ikoniczne na mapie Dolnego Śląska. Widoczna w promieniu kilkudziesięciu kilometrów, otoczona licznymi legendami i wpleciona w miejscowy folklor, od dawna stanowi ważne miejsce turystyczne oraz przedmiot zainteresowań licznego grona naukowców. Obszar u jej stóp był zasiedlony od tysięcy lat, co znajduje potwierdzenie w badaniach archeologicznych. Stoki góry i jej szczyt otaczają tajemnicze kręgi kamienne, w jej pobliżu odkryto również zagadkowe rzeźby kamienne. Zazwyczaj zakłada się, że Ślęża w pradziejach stanowiła ważny pogański ośrodek kultowo-religijny.

Z punktu widzenia zagadnień, którymi zajmuję się w niniejszym artykule, Ślęża jest miejscem o tyle istotnym, że choć stanowi(-ła) obiekt badań i dociekań naukowych, to zainteresowanie ową niezwykłą górą wykracza daleko poza dyskurs naukowy. Wiele osób wierzy, że jest ona miejscem o szczególnej mocy, neopoganie zjeżdżają się w jej okolice, aby kultywować przedchrześcijańskie obrzędy, natomiast zwolennicy kontaktów z pozaziemskimi cywilizacjami widzą tu idealne lądowisko dla UFO. W niniejszym tekście rozważania koncentrują się nie tyle wokół znaczenia Ślęży dla ludzi w pradziejach, ile raczej wokół jej współczesnej wymowy, ze szczególnym uwypukleniem różnorodnych funkcji, jakie spełnia ona w teraźniejszości.

W wystąpieniu proponuję spojrzenie na Ślężę przez pryzmat kategorii „,miejsc pamięci” (lieux de mémoire) zaproponowanej przez Pierre'a Norę. „Miejsce pamięci” to kategoria dość płynna, otwarta i pojemna, Nora nazywa nią wszelkie oznaki pamięci narodowej, publicznej, społecznej. Kategoria ta stanowi metaforę, nie odnosi się jedynie do topograficznie definiowanych miejsc, lecz ma o wiele szerszy zakres. Miejsca pamięci mogą mieć zarówno charakter materialny, jak i niematerialny: miejscem pamięci może być konkretna przestrzeń fizyczna, lecz również należą do nich realne i mityczne postaci i zdarzenia, budynki, pomniki, instytucje, pojęcia, wydarzenia, rytuały, instytucje, święta, obrazy, symbole itd., które stały się trwałym elementem pamięci zbiorowej. Za sprawą woli człowieka lub pod wpływem czasu stały się one elementem symbolicznym dziedzictwa pamięci określonej wspólnoty. Nora w celu badania miejsc pamięci zaproponował perspektywę, nazywaną przez niego „historią drugiego stopnia” (histoire au second degree), która pyta m.in. o powstawanie zbiorowych wyobrażeń o przeszłości, zmiany, jakim one podlegały i podlegają oraz rolę pamięci w procesach konstytuowania się tożsamości zbiorowych, co pozwala na „zwrócenie się ku przestrzeni symbolicznej, dowartościowanie zbiorowych imaginacji i kultury popularnej, analizę sposobów użycia i funkcjonowania przeszłości dla aktualnych potrzeb” (Kończal, 2009, s. 211). 
Góra Ślęża, jako punkt krystalizujący zbiorowe imaginarium, stanowi arenę manifestacji rozmaitych zachowań i odmiennych interpretacji. Ma ona znaczenie nie tylko z naukowego punktu widzenia, lecz jest istotna dla wielu ludzi z innych powodów, jak choćby czysto pragmatycznych (władze lokalne), estetycznych (turyści) czy też duchowych (radiesteci, ezoterycy). Jak staram się wykazać, opierając się na przykładzie Ślęży, koncepcja „miejsc pamięci” może być użyteczna w badaniu obecności reliktów przeszłości, w tym archeologicznych, w teraźniejszości, zwłaszcza pod kątem ich społecznego funkcjonowania, zróżnicowanych celów, jakim mogą służyć oraz narracjom, kreowanym wokół nich przez różne grupy osób. Kategoria ta pozwala mi odnieść się do zagadnienia społecznego funkcjonowania i znaczenia Ślęży, której obecna rola nie wynika jedynie ze znaczenia, jakie mogła posiadać i odgrywać w przeszłości, lecz przede wszystkim z jej współczesnego użycia. 